Agni Rimba Mawan, Sri Endah Indriwati, Suhadi. (2018). Aktivitas Antibakteri Ekstrak Metanol Buah Syzygium polyanthum terhadap Pertumbuhan Bakteri Escherchia coli. Vol. 4 (1) Pp. 64-68. Doi:

https:/ / doi.org/ 10.23917/ bioeksperimen.v4i1.2762

\title{
Aktivitas Antibakteri Ekstrak Metanol Buah Syzygium polyantbum terhadap Pertumbuhan Bakteri Escherchia coli
}

\author{
Agni Rimba Mawan*, Sri Endah Indriwati, Suhadi \\ Pendidikan Biologi Pascasarjana Universitas Negeri Malang \\ Jalan Semarang No. 5, Malang 65145 \\ *Email: agnirimba@gmail.com
}

\begin{abstract}
Abstrak
Buah salam (Syzygium polyanthum) memiliki manfaat sebagai obat. Penelitian ini bertujuan untuk mengetahui daya hambat ekstrak metanol buah Syzygium polyanthum terhadap pertumbuhan bakteri Escherchia coli. Ekstraksi dilakukan dengan cara maserasi menggunakan pelarut metanol. Konsentrasi ekstrak yang digunakan adalah 40\%, 60\%, dan $80 \%$, dengan tetracycline sebagai kontrol positif dan aquades sebagai kontrol negatif. Aktivitas antibakteri diuji menggunakan metode disk diffusion. Hasil uji aktivitas antibakteri dianalisis dengan menggunakan metode one way anova, dilanjutkan dengan uji LSD (least significance different). Hasil uji aktivitas antibakteri menunjukkan bahwa ekstrak buah Syzygium polyanthum berpengaruh signifikan dalam menghambat pertumbuhan bakteri Escherchia coli ( $\mathrm{p}<0,05)$. Konsentrasi $80 \%$ memiliki aktivitas paling tinggi dalam menghambat pertumbuhan bakteri Escherchia coli, yang tidak berbeda nyata dengan konsentrasi $60 \%$ dan kontrol positif. Kesimpulan dari penelitian ini adalah ekstrak metanol buah Syzygium polyanthum memiliki aktivitas antibakteri terhadap Escherchia coli.
\end{abstract}

Kata Kunci: aktivitas antibakteri, Syzygium polyanthum, Escherchia coli, metode disk diffusion

\section{Pendahuluan}

Indonesia memiliki beraneka ragam jenis tumbuhan. Hampir semua jenis tumbuhan dapat tumbuh di Indonesia. Sekitar 9.600 spesies yang tumbuhan di Indonesia berkhasiat sebagai obat dan kurang lebih 300 spesies di antaranya telah digunakan untuk bahan obat tradisional (Depkes RI, 2007).

Tumbuhan dapat digunakan sebagai obat karena mengandung senyawa bioaktif. Beberapa senyawa metabolit sekunder antara lain terpenoid, flavonoid, alkaloid, tanin, saponin, terpenoid, glikosida. Terpenoid berperan sebagai antikanker (Sun dkk., 2015). Flavonoid berperan sebagai antikanker (Xia dkk., 2013), antioksidan (Dewi dkk., 2014; Vijayakumar dkk., 2008), dan antiinflamasi (Guardia dkk., 2001). Alkaloid berperan sebagai antioksidan, antidiabet (Tiong dkk., 2013), dan antifungal (Zhang dkk., 2009). Tanin berperan sebagai antioksidan, anti-inflamasi (Park dkk., 2013), dan antidiabet (Hardoko dkk., 2016). Saponin berperan sebagai antioksidan (Akinpelu dkk., 2014) dan antifungal (Tsuzuki dkk., 2007). Terpenoid (Mariajancyrani dkk., 2013), flavonoid (Sukadana, 2010), alkaloid (Pfoze dkk., 2011), tanin (Doss dkk., 2009), dan saponin (Akinpelu dkk., 2014) juga memiliki aktivitas antibakteri.

Bakteriyang umum menjadi masalah kesehatan adalah Escherchia coli. Bakteri Escherchia coli dapat menyebabkan penyakit diare yang sampai saat ini masih menjadi masalah klinis yang harus ditangani. Masalah baru yang muncul adalah meningkatnya resistensi Escherchia coli terhadap berbagai antibiotik (Tadesse dkk., 2012), karena penggunaan obat antibiotik sintetik yang tidak terkontrol (Bisht dkk., 2009). Peningkatan resistensi Escherchia coli terhadap berbagai antibiotik mengharuskan untuk mencari obat antibakteri baru yaitu dari tumbuhan.

Tumbuhan yang akan diuji efek antibakteri dalam penelitian ini adalah tumbuhan salam (Syzygium polyanthum) yaitu bagian buah, yang akan digunakan untuk menghambat pertumbuhan bakteri Escherchia coli. Penelitian terdahulu melaporkan bahwa ekstrak etanol buah Syzygium polyanthum mengandung senyawa metabolit sekunder antara lain tanin, alkaloid, triterpenoid, dan flavonoid, yang memiliki aktivitas antibakteri yang dapat menghambat pertumbuhan Salmonella Thypi, Bacillus cereus, (Kusuma dkk., 2011). Berdasarkan penelitian terdahulu maka perlu dilakukan penelitian lebih lanjut terhadap buah 
Syzygium polyanthum dengan menggunakan pelarut metanol untuk ekstraksi, Escherchia coli sebagai bakteri uji.

Penelitian ini bertujuan untuk mengetahui aktivitas antibakteri dari ekstrak metanol buah Syzygium polyanthum terhadap pertumbuhan bakteri Escherchia coli.

\section{Metoe Penelitian}

Jenispenelitianiniadalah penelitian eksperimen dengan rancangan acak lengkap (RAL). Penelitian ini dilakukan pada bulan September-November 2016 di Laboratorium Kimia Unit Pelaksanaan Teknis Materia Medica Kota Batu dan Laboratorium Biologi FMIPA Universitas Negeri Malang. Bahan yang digunakan adalah buah Syzygium polyanthum yang masih mentah, didapatkan dari desa Argosuko Kecamatan Poncokusumo Kabupaten Malang. Isolat bakteri yang digunakan adalah bakteri Escherchia coli koleksi laboratorium biologi FMIPA Universitas Negeri Malang.

Buah Syzygium polyanthum diekstrak dengan metode maserasi menggunakan pelarut metanol. Ekstrak kemudian diuji fitokimia secara kualitatif untuk mengetahui ada atau tidaknya senyawa aktif flavonoid, alkaloid, terpenoid, tannin, dan saponin.

Ekstrak metanol buah Syzygium polyanthum diuji aktivitas antibakteri pada konsentrasi $40 \%$, $60 \%$, dan $80 \%$, dengan tetracycline sebagai kontrol positif dan aquades sebagai kontrol negatif, dilakukan secara in vitro menggunakan metode disk diffusion dan pengukuran zona hambat. Masingmasing perlakuan dilakukan pengulangan sebanyak lima kali dengan tahapan sebagai berikut.

1. Membuat media pertumbuhan bakteri NA (Nutrien Agar)

Sebanyak 6 gram NA dimasukkan ke dalam beaker glass yang berisi aquades $300 \mathrm{ml}$, kemudian dipanaskan dan diaduk hingga larutan homogen. Sebanyak $10 \mathrm{ml}$ medium NA dimasukkan ke dalam masing-masing cawan petri, dan $5 \mathrm{ml}$ ke dalam tabung reaksi. Media NA dalam cawan petri dan tabung reaksi kemudian disterilkan dalam autoklaf dengan suhu $121^{\circ} \mathrm{C}$ selama 15 menit. Media NA dalam cawan petri yang sudah di sterilkan ditunggu hingga membeku, sedangkan media yang ada di tabung reaksi diletakkan pada kemiringan $30^{\circ}$. Media agar miring digunakan untuk inokulum bakteri.

2. Membuat beberapa konsentrasi larutan uji Larutan uji yang digunakan adalah konsentrasi $40 \%$, 60\%, dan $80 \%$, dengan cara menimbang $0,4 \mathrm{~g} ; 0,6 \mathrm{~g}$; dan $0,8 \mathrm{~g}$ ekstrak metanol buah Syzygium polyanthum kemudian masing-masing ekstrak dilarutkan dalam $1 \mathrm{ml}$ aquades. Kontrol positif dibuat dengan melarutkan $500 \mathrm{mg}$ tetracycline ke dalam $1 \mathrm{ml}$ aquades .

3. Menguji Aktivitas Antibakteri

Sebanyak 5 jarum ose isolat bakteri dicelupkan ke dalam nutrien cair kemudian dihomogenkan dan diinkubasi selama 24 jam, setelah 24 jam cotton bud steril kemudian dicelupkan ke dalam biakan murni bakteri Escherchia coli dalam medium nutrien cair yang sudah berumur 24 jam dan dioleskan secara merata pada permukaan medium lempeng NA secara aseptik.

Paper disk dimasukkan ke dalam masingmasing konsentrasi ekstrak metanol buah Syzygium polyanthum, kontrol positif dan kontrol negatif selama 15 menit, kemudian paper disk diletakkan di atas media agar yang sudah diolesi bakteri Escherchia coli dengan ketentuan satu cawan petri satu paper disk. Bakteri kemudian diinkubasi pada suhu $37^{\circ} \mathrm{C}$ selama 24 jam, lalu diamati dan diukur diameter zona hambatnya. Data diameter zona hambat dianalisis secara statistik menggunakan metode one way anova (anova satu jalur) dengan menggunakan program SPSS (statistical product services solution) dengan taraf kepercayaan $95 \%$ atau $\mathrm{p}<0,05$, kemudian dilanjutkan dengan LSD test.

\section{Hasil dan Pembahasan}

\section{Analisis Fitokimia}

Hasil Analisis fitokimia secara kualitatif menunjukkan bahwa pada ekstrak metanol buah Syzygium polyanthum mengandung senyawa flavonoid, alkaloid, terpenoid, tannin, dan saponin. 


\section{Uji Aktivitas Antibakteri}

Hasil penelitian menunjukkan bahwa ekstrak metanol buah Syzygium polyanthum secara signifikan menghambat pertumbuhan bakteri $(\mathrm{p}<0,05)$ yang ditunjukkan adanya zona bening di sekitar paper disk (Gambar 1, panah biru).

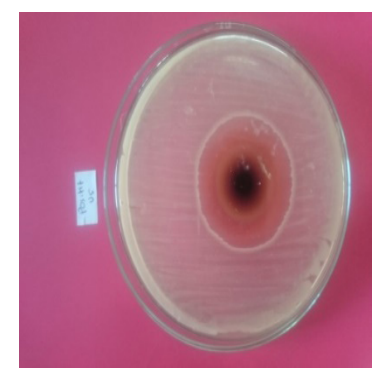

Gambar 1 Tanda panah warna biru (zona hambat), warna kuning (zat antibakteri), warna merah (bakteri Escherchia coli).

Zona bening terbentuk karena ekstrak yg ada pada paper disk berdifusi ke agar dan mencegah pertumbuhan bakteri Escherchia coli yang ada di daerah itu. Diduga campuran senyawa flavonoid, alkaloid, terpenoid, tannin, dan saponin yang bertanggung jawab menghambat pertumbuhan bakteri.

Senyawa flavonoid merupakan senyawa metabolit sekunder yang memiliki kemampuan untuk menghambat pertumbuhan bakteri (Sukadana, 2010). Aktivitas flavonoid dalam menghambat pertumbuhan bakteri yaitu dengan menyebabkan kerusakan pada membran sel dan menghambat sintesis makromolekul sel bakteri (Dzoyem dkk., 2013).

Senyawa tanin memiliki kemampuan untuk menghambat pertumbuhan bakteri (Min dkk, 2008). Aktivitas tanin dalam menghambat pertumbuhan antibakteri berkaitan dengan kemampuannya untuk berikatan dengan dinding sel bakteri, menghambat pertumbuhan dan aktivitas protease (Jones dkk., 1994).

Senyawa terpenoid memiliki kemampuan untuk menghambat partumbuhan bakteri (Mariajancyrani dkk., 2013). Aktivitasnya dalam menghambat pertumbuhan bakteri tidak sepenuhnya dipahami, tetapi diduga melibatkan gangguan membran oleh senyawa lipofilik (Cowan, 1999).
Senyawa alkaloid memiliki kemampuan untuk menghambat pertumbuhan bakteri (Pfoze dkk., 2011), kemampuan alkaloid dalam menghambat pertumbuhan bakteridikaitkan dengan kemampuan mereka berinterkalasi dengan DNA, sehingga menghambat sintesis DNA dan reverse transcriptase (Schmeller dkk., 1997), juga dengan melepaskan adhesin asam lipoteikoat dari permukaan sel (Sun dkk., 1988) sehingga mengganggu permeabilitas membran.

Senyawa saponin memiliki kemampuan untuk menghambatbakteri(Akinpeludkk.,2014).Aktivitas saponin dalam menghambat pertumbuhan bakteri adalah dengan mengurangi efisiensi pemanfaatan glukosa dalam mikroorganisme, mempengaruhi pertumbuhan dan proliferasi, mengurangi aktivitas enzim kunci dalam metabolisme fisiologis dan menekan sintesis protein, kemudian menyebabkan kematian sel (Zhi-hui dkk., 2013).

Konsentrasi $80 \%$ ekstrak metanol buah Syzygium polyanthum memiliki aktivitas paling tinggi dalam menghambat pertumbuhan bakteri E. coli, sedangkan konsentrasi $40 \%$ menunjukkan aktivitas antibakteri yang paling rendah. Hasil ini menjelaskan bahwa semakin tinggi konsentrasi maka semakin luas zona hambat yang terbentuk. Diduga dengan meningkatnya konsentrasi zat antibakteri, maka semakin tinggi senyawa aktif yang terkandung di dalamnya.

Dibandingkan dengan kontrol positif (tetracycline) $500 \mathrm{mg}$, ekstrak metanol buah Syzygium polyanthum menunjukkan daya hambat lebih rendah. Berdasarkan uji LSD, Konsentrasi 80\% dan 60\% memiliki daya hambat yang tidak berbeda signifikan, konsentrasi $80 \%$ juga tidak berbeda signifikan dengan kontrol positif. Konsentrasi terendah (40\%) menunjukkan daya hambat yang berbeda signifikan dengan kontrol positif, kontrol negatif, konsentrasi 60\% dan konsentrasi 80\%.

Adapun hasil pengukuran diameter zona hambat masing-masing perlakuan, menunjukkan rata-rata diameter zona hambat kontrol positif $(26,5$ $\mathrm{mm})$, konsentrasi 40\% (16,83 mm), 60\% (23,27 $\mathrm{mm})$, dan $80 \%(24,27 \mathrm{~mm})$, sedangkan kontrol negatif tidak menunjukkan adanya zona hambat $(0$ mm) (Tabel 1). 
Tabel 1 Daya hambat ekstrak metanol buah Syzygium polyanthum terhadap bakteri Escherchia

\begin{tabular}{cc}
\multicolumn{2}{c}{ coli } \\
\hline Perlakuan & $\begin{array}{c}\text { Rata-rata Diam- } \\
\text { eter } \\
\pm \text { SD }(\mathbf{m m})\end{array}$ \\
\hline Kontrol - (aquades) & $0,00 \pm 0,00^{\mathrm{c}}$ \\
Kontrol + (tetracycline) & $26,50 \pm 0,00^{\mathrm{a}}$ \\
Konsentrasi 40\% & $16,83 \pm 2,08^{\mathrm{d}}$ \\
Konsentrasi 60\% & $23,17 \pm 2,75^{\mathrm{b}}$ \\
Konsentrasi 80\% & $24,17 \pm 0,57^{\mathrm{ab}}$ \\
\hline
\end{tabular}

Angka yang diikuti oleh notasi huruf yang berbeda artinya berbeda signifikan berdasarkan uji LSD 0,05

\section{Kesimpulan}

Kesimpulan dari penelitian ini adalah terdapat pengaruh yang signifikan ekstrak metanol buah Syzygium polyanthum dalam menghambat pertumbuhan bakteri Escherchia coli.

\section{Daftar Rujukan}

Akinpelu, B. A., Igbeneghu, O. A., Awotunde, A. I., Iwalewa, E. O., dan Oyedapo, O. O. 2014. Antioxidant and Antibacterial Activities of Saponin Fractions of Erythropheleum suaveolens (Guill. And Perri.) Stem Bark Extract. Scientific Research and Essays, 9(18): 826-833.

Bisht, R., Katiyar, A., Singh, R., dan Mittal, P. 2009. Antibiotic Resistance-A Global Issue of Concern. Asian Journal of Pharmaceutical and Clinical Research, 2(2): 34-39.

Cowan, M.M. 1999. Plant Product as Antimicrobial Agents. J. Microbiology Reviews 12(4):564582.

Depkes RI. 2007. Kebijakan Obat Tradisional Nasional. Jakarta: Departemen Kesehatan RI.

Dewi, N. W. O. A. C., Puspawati, N. M., Swantara, I. M. D., Asih, I. A. R. A., dan Rita, W. S. 2014. Aktivitas Antioksidan Senyawa Flavonoid Ekstrak Etanol Biji Terong Belanda (Solanum betaceum, syn) dalam Menghambat Reaksi Peroksidasi Lemak pada Plasma Darah Tikus Wistar. Cakra Kimia (Indonesian E-Journal of Applied Chemistry), 2(1): 7-16.

Doss, A., Mubarack, M., dan Dhanabalan, R. 2009. Antibacterial Activity of Tannins from the Leaves of Solanum Trilobatum Linn. Indian Journal of Science and Technology, 2(2): 41-43.

Dyozem, J. P., Hamamoto, H., Ngameni, B., Ngadjui, B. T., dan Sekimizu, K. 2013. Antimicrobial Action Mechanism of Flavonoids from Dorstenia species. Drug Discoveries \& Therapeutics, 7(2): 66-72.

Guardia, T., Rotelli, A. E., Juarez, A. O., dan Pelzer L. E. 2001. Anti-inflammatory Properties of Plant Flavonoids. Effects of Rutin, Quercetin and Hesperidin on Adjuvant Arthritis in Rat. Farmaco, 56(9): 638-7.

Hardoko, Sasmito, B. B., dan Puspitasari, Y. E. 2016. Antidiabetic and Antioxidant Activities of Tannin Extract of Rhizophora mucronata Leaves. Journal of Chemical and Pharmaceutical Research, 8(3):143-148.

Jones, G. A., McAllister, T. A., Muir, A. D., dan Cheng, K. J. 1994. Effects of Sainfoin (Onobrychis viciifolia scop.) Condensed Tannins on Growth and Proteolysis by Four Strains of Ruminal Bacteria. Appl. Environ. Microbiol, 60 (4):1374-1378.

Kusuma, I. W., Kuspradini, H., Arung, E. T., Aryani, F., Min, Y. H., Kim, J. S., dan Kim, Y. U. 2011. Biological Activity and Phytochemical Analysis of Three Indonesian Medicinal Plants, Murraya koenigii, Syzygium polyanthum and Zingiber purpurea. J Acupunct Meridian Stud, 4(1): 75-79.

Mariajancyrani, J., Chandramohan, G., Saravanan, dan Elayaraja, A. 2013. Isolation and Antibacterial Activity of Terpenoid from Bougainvillea glabra Choicy Leaves. Asian Journal of 
Plant Science and Research, 3(3):70-73.

Park, M., Cho, H., Jung, H., Lee, H., dan Hwang, K. T. 2013. Antioxidant and Anti-Inflammatory Activities of Tannin Fraction of the Extract from Black Raspberry Seeds Compared to Grape Seeds. Journal of Food Biochemistry, 38(3): 259-270.

Pfoze, N. L., Kumar, Y., Myrboh, B., Bhagobaty, R. K., dan Joshi, S. R. 2011. In vitro Antibacterial Activity of Alkaloid Extract from Stem Bark of Mahonia manipurensis Takeda. Journal of Medicinal Plants Research, 5(5): 859-861.

Schmeller, T., Latz-Brüning, B., dan Wink, M. 1997. Biochemical Activities of Berberine, Palmatine and Sanguinarine Mediating Chemical Defence Against Microorganisms and Herbivores. Phytochemistry, 44(2): 257-266.

Sukadana, I. M. 2010. Aktivitas Antibakteri Senyawa Flavonoid dari Kulit Akar Awar-Awar (Ficus septica Burm F). Jurnal Kimia, 4(1): 63-70.

Sun, D., Courtney, H. S., dan Beachey, E. H. 1988. Barberine Sulfate Blocks Adherence of Streptococcus pyogenes to Epithelial Cells, Fibronectin, and Hexadecane. Antimicrobial Agents and Chemotherapy, 32(9): 1370-1374.

Sun, X. B., Wang, S. M., Li, T., dan Yang, Y. Q. 2015. Anticancer Activity of Linalool Terpenoid: Apoptosis Induction and Cell Cycle Arrest in Prostate Cancer Cells. Tropical Journal of Pharmaceutical Research, 14(4): 619-625.

Tadesse, D. A., Zhao, S., Tong, E., Ayers, S., Singh, A., Bartholomew, M. J., dan Patrick, F. 2012. Antimicrobial Drug Resistance in Eschercia coli from Humans and Food Animal, United States, 1950-2002. Emerging Infectious Diseases, 18(5): 741-749.

Tiong, S. H., Looi, C. Y., Hazni, H., Arya, A., Paydar, M., Wong, W. F., Cheah, S. C., Mustafa, M. R., dan Awang, K. 2013. Antidiabetic and Antioxidant Properties of Alkaloids from Catharanthus roseus (L.) G. Don. Molecules, 18(2013): 9770-9784.

Tsuzuki, J. K., Svidzinski, T. L., Shinobu, C. S., Silva, L. F. A., Rodrigues-Filho, E., Cortez, D. A. G., dan Ferreira, I. C. P. Antifungal Activity of the Extracts and Saponins from Sapindus saponaria L. Anais da Academia Brasileira de Ciências, 79(4): 577-583.

Vijayakumar, S., Presannakumar, G., dan Vijayalakshmi, N. R. 2008. Antioxidant Activity of Banana Flavonoids. Fitoterapia, 79(4): 279-82.

Xia, G., Matsidik, R., Ablise, M., Lei, S., dan Abudula, A. 2013. Anti-cancer Activity of Flavonoids from Xinjiang Glycyrrhiza inflata Licorice on Proliferation, Cytotoxicity and Apoptosis in Cervical Carcinoma Cells. Journal of Medicinal Plants Research, 7(5): 173-178.

Zhang, J. W., Gao, J. M., Xu, T., Zhang, X. C., Ma, Y. T., Jarussophon, S., dan Konishi, Y. 2009. Antifungal Activity of Alkaloids from the Seeds of Chimonanthus praecox. Chemistry \& Biodiversity, 6(6): 838-845.

Zhi-hui, Y., Xue-zhi, D., Li-qiu, X., Xiu-quing, X., Sha, X., Shuang, L., dan Xue-mei, L. 2013. Antimicrobial Activity and Mechanism of Total Saponins from Allium chinense. Food Science, 34(15): 75-80. 